\title{
Keterkaitan antara Susu sebagai Pelengkap Sarapan terhadap Prestasi Belajar Siswa Sekolah Dasar
}

\author{
Megah Stefani ${ }^{1}$, Fifi Khoirunnisa ${ }^{2}$, Zulhijah Wulandari ${ }^{3}$ \\ 1,2,3 Program Studi Gizi, Universitas Sahid Jakarta, Indonesia \\ Email: megah_stefani@usahid.ac.id
}

\begin{abstract}
The study aims to determine the association of milk as complimentary breakfast towards learning achievement of elementary school students, using a retrospective case-control research design. Subjects were determined purposively with the inclusion criteria having normal BMI and not lactose intolerance. The minimum number of subjects was based on calculations were 38 children. Subjects as many as 22 elementary school children were exposed to a complete breakfast habit with milk and 17 elementary school children became a control group for breakfast habits without milk. Completing the $2 \times 24$ hour food recall questionnaire and 7-day food record and subject interviews were conducted for 1 week. Learning achievement is measured using the final score of the semester 1 by K13 curriculum. There was a significant relationship in the exposed group and the control group on learning achievement especially Bahasa scores $(p=0,001)$ as many as 90,91\% in the exposed group and 88,24\%, in the control group, also, the tendency for a better IPA (Science) scores in the exposed group was 81,82\% compared to the control group at 64,71\%. Thus, the habit of breakfast supplemented with milk is closely related to the learning achievement of elementary school children.
\end{abstract}

Keywords: Breakfast, milk, elementary school children, learning achievement

\begin{abstract}
Abstrak
Penelitian ini bertujuan mengetahui keterkaitan susu sebagai pelengkap sarapan terhadap prestasi belajar siswa sekolah dasar, menggunakan desain penelitian case-control. Subjek ditentukan secara purposive dengan kriteria inklusi memiliki IMT normal dan tidak lactose intolance. Jumlah subjek minimal berdasarkan perhitungan yaitu 38 anak. Subjek sebanyak 22 anak sekolah dasar menjadi kelompok terpapar kebiasaan sarapan lengkap dengan susu dan 17 anak sekolah dasar menjadi kelompok kontrol kebiasaan sarapan tanpa susu. Pengisian kuesioner food recall 2x24 jam dan food record 7 hari serta wawancara subjek dilaksanakan selama 1 minggu. Prestasi belajar diukur menggunakan nilai akhir rapot K13 semester 1. Terdapat hubungan yang signifikan pada kelompok terpapar dan kelompok kontrol terhadap prestasi belajar terutama nilai Bahasa Indonesia $(\mathrm{p}=0,001)$ yaitu sebanyak $90,91 \%$ nilai kategori baik pada kelompok terpapar dan sejumlah $88,24 \%$ pada kelompok kontrol serta kecenderungan nilai IPA yang lebih baik pada kelompok terpapar yaitu 81,82\% dibandingkan kelompok kontrol sebesar 64,71\%, sehingga kebiasaan sarapan dilengkapi dengan susu berkaitan dengan prestasi belajar anak sekolah dasar.
\end{abstract}

Kata Kunci: Sarapan, susu, siswa sekolah dasar, prestasi belajar 


\section{PENDAHULUAN}

Indonesia masih menghadapi masalah gizi ganda (kekurangan dan kelebihan gizi). Upaya yang dapat dilakukan untuk mengatasinya dengan mewujudkan gizi seimbang. Berdasarkan Laporan Riskesdas tahun 2018 (Kemenkes RI, 2018), prevalensi gizi buruk dan kurang yaitu 17,7\%, gizi lebih dengan prevalensi sebanyak 8,0\%, dan stunting sebesar 30,8\% pada balita di Indonesia. Kecukupan gizi memiliki peran penting pada masa balita hingga usia sekolah untuk menjamin anak-anak dapat tumbuh dan kembang secara maksimal.

Pada masa pertumbuhan dan perkembangan tersebut seorang anak membutuhkan sejumlah zat gizi yang harus didapatkan dari konsumsi makanan dengan jumlah yang cukup dan sesuai dengan angka kebutuhan yang dianjurkan setiap harinya (Brown, 2004). Hal tersebut dapat dipenuhi dengan melakukan beberapa pilar pedoman gizi seimbang yaitu kebiasaan sarapan dan konsumsi makanan yang beragam, berimbang, dan bergizi. Anak Indonesia cenderung kelebihan konsumsi pangan sumber karbohidrat tetapi kurang sayur, buah, lauk hewani dan susu (Hardiansyah, Hardinsyah and Sukandar, 2017). Kebiasaan sarapan anak juga dilaporkan kurang baik dan menjadi perhatian utama. Prevalensi tidak terbiasa sarapan pada anak dan remaja 16,9-59\% sedangkan pada orang dewasa 31,2\% (Pergizi Pangan Indonesia, 2013).

Sarapan merupakan salah satu pola makan yang penting untuk mewujudkan gizi seimbang, tetapi kenyataannya masih banyak siswa sekolah dasar yang tidak atau belum terbiasa sarapan. Sarapan penting bagi siswa sekolah dasar untuk memenuhi kebutuhan zat gizi dan mengawali aktivitas di pagi hari. Manfaat sarapan ditinjau dari aspek edukasi dan kognitif menurut (Phillips, 2005) antara lain: meningkatkan frekuensi kehadiran di sekolah; mengurangi keterlambatan hadir di sekolah; meningkatkan konsentrasi, kewaspadaan, dan perhatian atau atensi terhadap pelajaran; meningkatkan kemampuan pemahaman, belajar, memori, serta pemecahan masalah; meningkatkan nilai ujian matematika (aritmatika), IPA (science), IPS, Bahasa Inggris (kosa kata dan tata bahasa); dan meningkatkan kreativitas dan prestasi belajar.

Menu sarapan yang beragam, seimbang, dan bergizi perlu diperhatikan. Kebiasaan sarapan siswa sekolah dasar pada dua sekolah dasar di Jakarta Selatan menunjukkan bahwa 56,19\% siswa sekolah dasar selalu sarapan, dengan persentase jenis sarapan yang sering dikonsumsi yaitu susu (46,30\%) sebagai menu sarapan (Stefani, Megah; Kustiyah, 2019). Susu merupakan makanan alami yang hampir sempurna, sebagian besar zat gizi esensial ada dalam susu diantaranya yaitu protein, kalsium, fosfor, vitamin A, dan tiamin (vitamin B1). Susu merupakan sumber kalsium paling baik karena disamping kadar kalsium yang tinggi, laktosa di dalam susu membantu absorpsi susu di dalam saluran cerna (Almatsier, 2009). 
Pentingnya susu bagi kesehatan tidak hanya menyangkut masalah osteoporosis. Susu juga diketahui memberikan manfaat untuk optimalisasi produksi melatonin. Susu yang mengandung banyak asam amino triptofan merupakan salah satu bahan dasar melatonin. Melatonin adalah hormon yang dihasilkan oleh kelenjar pineal pada malam hari. Kehadiran melatonin akan membuat kita merasa mengantuk dan kemudian tubuh bisa beristirahat dengan baik (Khomsan, 2004).

Susu memiliki kandungan gizi lengkap dan manfaat yang sangat baik, tetapi konsumsi susu di Indonesia masih sangat rendah dibandingkan dengan negara lain seperti India, Cina, dan Malaysia. Rata-rata anak Indonesia mengonsumsi susu sekitar 87,1 ml per hari dengan distribusi yang beragam (Hardiansyah, Hardinsyah and Sukandar, 2017). Berbagai permasalahan di atas, mengakibatkan peran gizi penting selama usia sekolah untuk menjamin anak-anak meraih pertumbuhan dan perkembangan optimal yang dapat dilakukan dengan melakukan kebiasaan sarapan setiap hari dan melengkapi menu sarapan tersebut dengan konsumsi susu untuk mengetahui keterkaitan antara kebiasaan sarapan dengan menu lengkap dengan susu terhadap prestasi belajar siswa sekolah dasar.

\section{METODE}

\section{Desain, Waktu, dan Tempat}

Desain penelitian yang digunakan adalah case-control. Subjek dikelompokkan menjadi 2 kelompok yaitu kelompok terpapar : kelompok sarapan lengkap dengan susu dan kelompok sarapan tanpa susu sebagai kontrol. Penelitian ini dilaksanakan pada November-Desember 2018 di Jakarta Selatan. Perijinan penelitian ini melalui informed consent yang telah disetujui oleh orangtua subjek dan kepala sekolah. Pemilihan tempat penelitian secara purposive karena terkait hasil penelitian sebelumnya pada sekolah dasar yang sama pada tahun 2012 (retrospektif).

\section{Jumlah dan Cara Pengambilan Sampel}

Subjek merupakan siswa kelas 5 di SDN 02 Pagi Pesanggrahan, Jakarta Selatan. Pemilihan subjek penelitian ini dilakukan secara purposive. Terdapat beberapa kriteria yang harus dipenuhi untuk menjadi subjek dalam penelitian ini. Kriteria inklusi adalah IMT normal dan tidak lactose intolance. Kriteria eksklusi adalah subjek yang memiliki kebiasaan tidak pernah sarapan. Jumlah subjek dalam penelitian ini adalah 39 siswa : sebagai kelompok kontrol sebanyak 22 siswa dan 17 siswa sebagai kelompok terpapar. Subjek yang memenuhi kriteria diminta orang tuanya untuk mengisi informed consent, mau berpartisipasi dan melibatkan peran orang tua untuk berkomitmen penuh memandu subjek di rumah untuk mengisi kuesioner. 


\section{Pengolahan dan Analisis Data}

Subjek selama penelitian diminta untuk mengisi beberapa kuesioner sebagai sumber data primer yang terdiri dari data karakteristik subjek dan sosial-ekonomi orang tua subjek, kebiasaan sarapan dan konsumsi susu, konsumsi pangan (kombinasi form record 7 hari dengan form recall 2x24 jam). Sumber data sekunder yaitu data leger nilai rapot K13 semester 1 siswa kelas 5A, 5B, dan 5C. Data kebiasaan sarapan dan konsumsi susu saat sarapan diperoleh dari hasil pengisian kuesioner dan wawancara secara langsung. Data konsumsi pangan siswa diperoleh dari hasil pengisian formulir food record 7 hari dan food recall 2x24 jam. Data status gizi diperoleh dari pengukuran secara langsung menggunakan timbangan digital dan microtoise. Analisis secara deskriptif yang dilakukan pada penelitian ini meliputi uji beda yaitu independent t-test antara kebiasaan sarapan lengkap dengan susu dengan prestasi belajar dan uji beda antara status gizi dengan prestasi belajar. Hasil disajikan dalam bentuk persentase sebaran dengan signifikansi hasil $\mathrm{p}<0,05$.

\section{HASIL DAN PEMBAHASAN}

Sekolah dan orangtua mempunyai peran yang penting untuk menerapkan kebiasaan sarapan. Pendidikan gizi di sekolah sangat perlu bagi anak usia sekolah khususnya siswa sekolah dasar. Menurut penelitian (Hafizhatunnisa, Damayanti and Darni, 2018), menunjukkan bahwa pemberian komik islami tentang sarapan sehat pada siswa sekolah dasar signifikan berpengaruh terhadap pengetahuan gizi siswa sekolah dasar terhadap manfaat sarapan. Peran orang tua dalam menerapkan kebiasaan sarapan pada anak setiap pagi, juga tidak kalah penting. Kebiasaan sarapan pagi termasuk salah satu pola makan yang harus diterapkan kepada anak-anak.

Kategori anak sebagai subjek dalam penelitian ini adalah siswa sekolah dasar. Secara keseluruhan jumlah subjek dalam penelitian ini berjumlah 84 siswa sekolah dasar yang dibagi menjadi dua kategori yaitu 42 siswa kelompok terpapar dan 42 siswa kelompok kontrol. Berdasarkan kriteria inklusi dalam penelitian ini, subjek harus yang terbiasa sarapan pagi dan mempunyai status gizi normal. Berdasarkan kriteria tersebut, subjek yang dapat diikutsertakan dalam penelitian ini sebanyak 39 siswa yaitu 22 pada kelompok terpapar dan 17 pada kelompok kontrol. Berikut tersaji data pada Tabel 1.

Berdasarkan Tabel 1, banyak subjek mengalami overweight dan obesitas terutama pada kelompok kontrol sebanyak 21,43\% dan 26,19\% yang berarti bahwa hampir setengah dari subjek mengalami kelebihan gizi. Adapun pada kelompok kontrol, jumlah subjek kelompok terpapar yang mengalami overweight sejumlah 9,52\% dan yang mengalami obesitas hampir seperempat yaitu 23,81\%. Berdasarkan data tersebut dapat disimpulkan bahwa double burden masih terjadi di sekolah ini, hal ini 
disebabkan masih ada subjek yang mengalami gizi kurang, sejumlah 9,52\% subjek berstatus gizi kurus dan 3,57\% subjek sangat kurus.

\section{Tabel 1. Sebaran dan Uji Beda Status Gizi dan Pola Sarapan antara Kelompok Terpapar dan Kontrol}

\begin{tabular}{|c|c|c|c|c|c|c|c|}
\hline Variabel & \multicolumn{2}{|c|}{ Terpapar } & \multicolumn{2}{|c|}{ Kontrol } & \multicolumn{2}{|c|}{ Total } & $\mathrm{p}(<0,05)$ \\
\hline \multicolumn{8}{|l|}{ Status gizi } \\
\hline Sangat kurus $(\mathrm{z}<-3)$ & 2 & 4,76 & 1 & 2,38 & 3 & 3,57 & \multirow{5}{*}{$0,00^{\mathrm{a}}$} \\
\hline Kurus $(-3<z \leq-2)$ & 4 & 9,52 & 4 & 9,52 & 8 & 9,52 & \\
\hline Normal $(-2<z \leq 1)$ & 22 & 52,38 & 17 & 40,48 & 39 & 46,43 & \\
\hline Overweight $(1<z \leq 2)$ & 4 & 9,52 & 9 & 21,43 & 13 & 15,48 & \\
\hline Obese $(z>2)$ & 19 & 23,81 & 11 & 26,19 & 30 & 35,71 & \\
\hline Total & 42 & 100 & 42 & 100 & 84 & 100 & \\
\hline \multicolumn{8}{|l|}{ Kebiasaan sarapan } \\
\hline $\begin{array}{l}\text { Jarang } \\
(<4 \mathrm{x} / \text { minggu })\end{array}$ & 6 & 27,27 & 11 & 64,71 & 17 & 45,99 & \multirow{4}{*}{$0,02^{\mathrm{a}}$} \\
\hline $\begin{array}{l}\text { Sering } \\
(\geq 4-6 x / \text { minggu })\end{array}$ & 6 & 27,27 & 3 & 17,65 & 9 & 22,26 & \\
\hline Selalu $(7 \mathrm{x} / \mathrm{minggu})$ & 10 & 45,45 & 3 & 17,65 & 13 & 31,6 & \\
\hline Total & 22 & 100 & 17 & 100 & 39 & 100 & \\
\hline \multicolumn{8}{|l|}{ Menu sarapan } \\
\hline Nasi \& lauk pauk & 7 & 33,33 & 6 & 35,29 & 13 & 33,33 & \multirow{8}{*}{$0,00^{a}$} \\
\hline Nasi uduk & 5 & 22,73 & 5 & 29,41 & 10 & 25,64 & \\
\hline Nasi kuning & 5 & 22,73 & 0 & 0 & 5 & 12,82 & \\
\hline Mie goreng & 0 & 0 & 2 & 11,76 & 2 & 5,13 & \\
\hline Roti & 2 & 9,09 & 1 & 5,88 & 3 & 7,69 & \\
\hline Nasi goreng & 0 & 0 & 2 & 11,76 & 2 & 5,13 & \\
\hline Bubur ayam & 1 & 4,55 & 0 & 0 & 1 & 2,56 & \\
\hline Lainnya & 1 & 4,55 & 1 & 5,88 & 2 & 5,13 & \\
\hline Total & 22 & 100 & 17 & 100 & 39 & 100 & \\
\hline
\end{tabular}

Keterangan: aindependent t-test antara terpapar dan kontrol

Jumlah subjek yang memiliki status gizi normal sebanyak 52,38\% pada kelompok terpapar sedangkan kelompok kontrol sebanyak 40,48\%. Hasil uji beda independent t-test menunjukkan bahwa terdapat perbedaan yang signifikan $(\mathrm{p}<0,05)$ antara status gizi pada kelompok terpapar dan kelompok kontrol. Subjek yang terbiasa sarapan dilengkapi susu akan mempunyai status gizi yang normal dibandingkan dengan subjek yang terbiasa sarapan tanpa dilengkapi dengan konsumsi susu. Berdasarkan penelitian (Mayangsari, Wahyuningtyas and Puspita, 2018) selain kebiasaan sarapan yang mempengaruhi status gizi, terdapat hubungan signifikan antara aktifitas fisik, durasi tidur, dan kebiasaan konsumsi fast food yang menjadi faktor risiko penentu status gizi pada anak.

Sarapan yang mengandung karbohidrat yang dicerna lebih lambat secara bertahap akan melepaskan glukosa ke dalam darah dalam periode yang lebih lama (Mahoney et al., 2005). Pelepasan glukosa yang lebih lambat dikaitkan dengan 
memori yang lebih baik di pagi hari, sehingga sarapan lengkap dengan susu sebagai sumber karbohidrat yang bernilai indeks glikemik rendah dapat membantu proses glucose loading yang lebih lama. Subjek mempunyai frekuensi kebiasaan sarapan yang bervariasi yaitu jarang sebanyak 27,27\% kelompok terpapar dan 64,71\% kelompok kontrol. Frekuensi sering sebanyak 27,27\% kelompok terpapar dan 17,65\% kelompok kontrol, dan frekuensi selalu sarapan sebanyak 45,45\% kelompok terpapar dan 17,65\% kelompok kontrol.

Berdasarkan data tersebut, frekuensi kelompok terpapar untuk selalu sarapan pagi sudah hampir setengah dari subjek, berbeda dengan kelompok kontrol frekuensi yang selalu sarapan sebanyak 17,65\% dan yang jarang sarapan sebesar 64,71\%. Subjek sudah mempunyai kebiasaan sarapan pagi, tetapi frekuensi untuk sarapan pagi masih sangat bervariasi. Pada kelompok kontrol lebih banyak pada kategori jarang sarapan sedangkan pada kelompok terpapar lebih banyak pada kategori selalu sarapan. Berbagai alasan yang disampaikan oleh subjek antara lain: bangun kesiangan atau ibu tidak menyediakan menu sarapan pagi setiap hari. Orangtua memberikan uang jajan yang sudah termasuk untuk membeli menu sarapan di sekolah, tetapi pada saat di sekolah subjek mengalokasikan bukan untuk sarapan tetapi untuk membeli jajanan seperti batagor, burger, gorengan, dan berbagai makanan ringan lainnya.

Berdasarkan hasil uji beda independent t-test, terdapat perbedaan signifikan $(\mathrm{p}<0,05)$ antara kelompok terpapar dengan kelompok kontrol yang menunjukkan bahwa subjek yang selalu sarapan pagi akan melengkapi sarapannya dengan konsumsi susu. Menu sarapan subjek yang sudah mempunyai kebiasaan sarapan dari berbagai jenis frekuensi tersebut juga sangat bervariasi. Subjek paling banyak sarapan dengan mengonsumsi nasi \& lauk pauk pada kelompok terpapar yaitu 33,33\% dan kontrol 35,29\%. Lauk pauk untuk sarapan yang dikonsumsi kelompok terpapar yaitu ayam goreng, telur goreng, ikan goreng, dan sayur sop serta sayur asem. Adapun lauk pauk untuk sarapan pada kelompok kontrol antara lain ayam goreng dan telur goreng.

Perbedaan signifikan menunjukkan bahwa antara subjek yang terpapar sarapan dilengkapi susu akan mempunyai menu sarapan yang lebih beragam, bergizi, dan berimbang jika dibandingkan dengan subjek kontrol. Hal ini sejalan dan didukung oleh hasil data food record selama 7 hari dan food recall 2x24 jam yang menunjukkan bahwa kelompok terpapar mempunyai menu makanan sarapan yang lebih beragam dibandingkan dengan kelompok kontrol. Hasil tersebut menunjukkan bahwa kebiasaan menambahkan susu pada menu sarapan memberikan dampak positif bagi subjek untuk mengonsumsi makanan pada waktu sarapan menjadi lebih beragam, berimbang, dan bergizi.

Kebiasaan sarapan dengan menu lengkap dan konsumsi susu saat sarapan pagi dan kaitannya dengan prestasi belajar disajikan pada Tabel 2. Kebiasaan sarapan 
mempunyai banyak manfaat positif bagi anak usia sekolah terutama pada aspek edukasi dan kognitif. Manfaat positif tersebut yaitu meningkatkan frekuensi kehadiran di sekolah; mengurangi keterlambatan hadir di sekolah; meningkatkan konsentrasi; meningkatkan nilai ujian matematika, IPA, IPS, Bahasa Inggris (kosa kata dan tata bahasa); dan meningkatkan kreativitas dan prestasi belajar (Phillips, 2005). Penelitian lainnya yang menunjukkan manfaat sarapan yaitu di Swedia, anak usia sekolah yang berusia 10 tahun, yang melakukan sarapan lengkap yang bergizi, berimbang, dan beragam akan mempunyai kemampuan berolahraga lebih lama di kelas senam pagi dan menunjukkan kemampuan verbal yang lebih baik (Benton, 2008).

\section{Tabel 2. Sebaran dan Uji Beda Prestasi Belajar antara Kelompok Terpapar dan Kontrol}

\begin{tabular}{|c|c|c|c|c|c|c|}
\hline \multirow{2}{*}{ Mata Pelajaran } & \multicolumn{2}{|c|}{ Terpapar } & \multicolumn{2}{|c|}{ Kontrol } & \multicolumn{2}{|c|}{ Total } \\
\hline & $\mathrm{n}$ & $\%$ & $\mathbf{n}$ & $\%$ & $\mathrm{n}$ & $\%$ \\
\hline \multicolumn{7}{|l|}{ Matematika } \\
\hline Baik & 12 & 54,55 & 11 & 64,71 & 23 & 58,97 \\
\hline Lebih dari cukup & 9 & 40,91 & 5 & 29,41 & 14 & 35,90 \\
\hline Cukup & 1 & 4,55 & 1 & 5,88 & 2 & 5,13 \\
\hline \multicolumn{7}{|c|}{$(\mathrm{p}<0,05)^{\mathrm{a}}=0,84$} \\
\hline \multicolumn{7}{|l|}{ IPA } \\
\hline Baik & 18 & 81,82 & 11 & 64,71 & 29 & 74,36 \\
\hline Lebih dari cukup & 4 & 18,18 & 6 & 35,29 & 10 & 25,64 \\
\hline Cukup & 0 & 0,00 & 0 & 0,00 & 0 & 0,00 \\
\hline \multicolumn{7}{|c|}{$(\mathrm{p}<0,05)^{\mathrm{a}}=0,07$} \\
\hline \multicolumn{7}{|l|}{ Bahasa Indonesia } \\
\hline Baik & 20 & 90,91 & 15 & 88,24 & 35 & 89,74 \\
\hline Lebih dari cukup & 2 & 9,09 & 2 & 11,76 & 4 & 10,26 \\
\hline Cukup & 0 & 0,00 & 0 & 0,00 & 0 & 0,00 \\
\hline \multicolumn{7}{|c|}{$(\mathrm{p}<0,05)^{\mathrm{a}}=0,00$} \\
\hline
\end{tabular}

Keterangan: aindependent t-test antara terpapar dan kontrol

Jenis susu yang paling sering dikonsumsi oleh subjek berdasarkan data konsumsi pangan, diurutkan sesuai jumlah terbanyak dikonsumsi oleh subjek yaitu susu bubuk whole milk (40,91\%), susu bubuk low fat (13,64\%), dan susu UHT $(45,45 \%)$. Banyak subjek yang mengonsumsi susu rasa coklat dengan alasan rasa yang lebih nikmat. Berbagai jenis susu yang telah disebutkan sebelumnya, memiliki kandungan zat gizi makro dan mikro yang beragam. Namun, berdasarkan penelitian (Lien et al., 2009), jenis susu yang dijadikan sebagai indikator dalam proses pembelajaran yang lebih baik yaitu susu fortifikasi (fortified milk). Hal ini disebabkan kandungan zat gizi makro dan mikro yang lebih banyak dan lengkap menjadikan anak usia sekolah yang mengonsumsi susu terfortifikasi menunjukkan kinerja yang unggul dibandingkan dengan kelompok minum susu biasa. 
Penelitian ini mengkaji tentang keterkaitan antara konsumsi susu saat sarapan dengan menu yang lengkap terhadap peningkatan prestasi belajar anak sekolah dasar. Hasil penelitian menunjukkan bahwa menu sarapan terbanyak yaitu nasi dan lauk pauk seperti lauk hewani dan sayur. Jenis susu yang dikonsumsi oleh subjek pada penelitian ini yaitu susu bubuk wholemilk, susu bubuk low fat, dan susu UHT. Merek dagang susu yang sering dikonsumsi oleh subjek yaitu Dancow, HiLo, Indomilk, Ultra, Frisian Flag. Konsumsi susu sebagai sumber karbohidrat yang bernilai indeks glikemik rendah dapat membantu proses glucose loading yang lebih lama, sehingga daya memori dan konsentrasi belajar anak usia sekolah lebih baik di pagi hari (Mahoney et al., 2005).

Beberapa penelitian yang mengaitkan konsumsi makanan rendah indeks glikemik saat sarapan terhadap peningkatan kognitif anak, yaitu ada empat penelitian (Mahoney et al., 2005; Ingwersen et al., 2007; Cooper et al., 2012; Defeyter dan Russo, 2013) menyatakan bahwa terjadi peningkatan kognitif dengan pilihan sarapan makanan rendah indeks glikemik. Namun, tidak satupun dari studi tersebut yang secara independen mengukur nilai indeks glikemik dari satu makanan dengan indeks glikemik rendah tetapi semua jenis makanan dihitung nilai indeks glikemiknya.

Prestasi belajar subjek dinilai melalui nilai mata pelajaran matematika, IPA dan Bahasa Indonesia. Pemilihan mata pelajaran ini disesuaikan dengan kurikulum yang digunakan oleh sekolah yaitu kurikulum K13 serta hasil berbagai penelitian sebelumnya. Penilaian yang menjadi acuan hanya bagian nilai pengetahuan. Berbagai penelitian sebelumnya menunjukkan bahwa terdapat hubungan antara konsumsi susu anak usia sekolah dengan prestasi akademik yang signifikan berkolerasi dengan peningkatan skor mata pelajaran Bahasa Korea, Ilmu Pengetahuan Sosial, dan Matematika (Kim, Kim and Kang, 2016). Penelitian di Vietnam juga menunjukkan bahwa terdapat pengaruh antara konsumsi susu terfortifikasi dengan perfoma belajar anak usia sekolah yaitu meningkatnya daya ingat jangka pendek anak usia sekolah (Lien et al., 2009).

Berdasarkan data pada Tabel 2, kelompok terpapar (54,55\%) nilai kategori baik pada mata pelajaran Matematika lebih sedikit dibandingkan dengan kelompok kontrol $(64,71 \%)$. Hasil analisis uji beda independent t-test menunjukkan bahwa tidak terdapat perbedaan signifikan $(\mathrm{p}>0,05)$ antara nilai matematika antara kelompok terpapar dan kelompok kontrol. Untuk mata pelajaran IPA (Ilmu Pengetahuan Alam), nilai kategori baik pada kelompok terpapar lebih banyak 81,82\% dibandingkan dengan kelompok kontrol yaitu sebanyak 64,71\%. Berdasarkan hasil uji beda menunjukkan bahwa tidak terdapat perbedaan signifikan $(\mathrm{p}>0,05)$ pada nilai IPA antara kelompok terpapar dan kelompok control. Namun, terdapat kecenderungan nilai IPA pada kelompok terpapar lebih baik dibandingkan kelompok kontrol. 
Selain mata pelajaran berbasis science, mata pelajaran berbasis linguistik seperti Bahasa Indonesia juga menjadi bagian penilaian yaitu sebanyak 90,91\% termasuk dalam nilai kategori baik pada kelompok terpapar dan sejumlah 88,24\% nilai kategori baik pada kelompok kontrol. Berdasarkan hasil analisis menunjukkan bahwa terdapat perbedaan signifikan $(\mathrm{p}<0,05)$ yaitu nilai Bahasa Indonesia antara kelompok sarapan dilengkapi dengan susu dengan kelompok sarapan non-susu. Hal ini sejalan dengan penelitian (Kim, Kim and Kang, 2016), menyatakan bahwa di Korea, konsumsi susu anak usia sekolah dengan prestasi akademik yang signifikan berkolerasi dengan peningkatan skor mata pelajaran Bahasa Korea. Penelitian di Vietnam juga menunjukkan bahwa kelompok subjek yang selalu minum susu terfortifikasi mempunyai hubungan signifikan dalam mengingat kata dibandingkan dengan subjek yang tidak terbiasa minum susu (Lien et al., 2009).

\section{KESIMPULAN}

Terdapat hubungan yang signifikan pada kelompok terpapar dan kelompok kontrol terhadap prestasi belajar terutama nilai Bahasa Indonesia $(p=0.001)$. Penelitian ini membuktikan bahwa kebiasaan selalu sarapan dengan menu lengkap disertai konsumsi susu saat sarapan akan meningkatkan performa prestasi anak sekolah dasar. Sehingga, rekomendasi untuk membentuk kebiasaan sarapan pagi secara teratur dan menu sarapan dilengkapi dengan konsumsi susu bagi anak usia sekolah dasar harus diupayakan sehingga performa kognitif anak diharapkan dapat meningkat. Rekomendasi ini membutuhkan dukungan dan kerjasama antar berbagai pihak yaitu orangtua, anak, guru, sekolah, dinas dan kementerian pendidikan dan kebudayaan, serta pemerintahan.

\section{DAFTAR PUSTAKA}

Almatsier, S. (2009) Prinsip Dasar Ilmu Gizi, PT Gramedia Pustaka Utama, Jakarta.

Benton, D. (2008) 'The influence of children's diet on their cognition and behavior', European Journal of Nutrition, 47(3), pp. 25-37. doi: 10.1007/s00394-008-3003-x.

Brown, J. E. (2004) 'Dietary Reference Intakes', Nutrition Reviews, 62(10), pp. 400-401. doi: 10.1111/j.1753-4887.2004.tb00011.x.

Cooper, S. B. et al. (2012) 'Breakfast glycaemic index and cognitive function in adolescent school children', British Journal of Nutrition, 107(12), pp. 1823-1832. doi: 10.1017/S0007114511005022.

Defeyter, M. A. and Russo, R. (2013) 'The effect of breakfast cereal consumption on adolescents' cognitive performance and mood', Frontiers in Human Neuroscience, (NOV). doi: 10.3389/fnhum.2013.00789. 
Hafizhatunnisa, H., Damayanti, A. Y. and Darni, J. (2018) 'The Effect of Healthy Breakfast Education with Islamic Comic Media on The Level of Knowledge of Elementary School Students', Nutri-Sains: Jurnal Giži, Pangan dan Aplikasinya. doi: 10.21580/ns.2018.2.2.3308.

Hardiansyah, A., Hardinsyah, H. and Sukandar, D. (2017) 'Kesesuaian Konsumsi Pangan Anak Indonesia Dengan Pedoman Gizi Seimbang', Nutri-Sains: Jurnal Gizi, Pangan dan Aplikasinya, 1(2), p. 35. doi: 10.21580/ns.2017.1.2.2452.

Ingwersen, J. et al. (2007) 'A low glycaemic index breakfast cereal preferentially prevents children's cognitive performance from declining throughout the morning', Appetite, 49(1), pp. 240-244. doi: 10.1016/j.appet.2006.06.009.

Kemenkes RI (2018) 'Hasil Utama Riskesdas 2018'.

Khomsan, A. (2004) Peranan pangan dan gizi untuk kualitas bidup, Buletin Penelitian Kesehatan. Yogyakarta: Grasindo.

Kim, S. H., Kim, W. K. and Kang, M. H. (2016) Relationships between milk consumption and academic performance, learning motivation and strategy, and personality in Korean adolescents, Nutrition Research and Practice. doi: 10.4162/nrp.2016.10.2.198.

Lien, D. T. K. et al. (2009) 'Impact of milk consumption on performance and health of primary school children in rural Vietnam', Asia Pacific Journal of Clinical Nutrition, 18(3), pp. 326-334. doi: 10.6133/apjcn.2009.18.3.04.

Mahoney, C. R. et al. (2005) 'Effect of breakfast composition on cognitive processes in elementary school children', Physiology and Behavior, 85(5), pp. 635-645. doi: 10.1016/j.physbeh.2005.06.023.

Mayangsari, A. R., Wahyuningtyas, W. and Puspita, I. D. (2018) 'The Relationship of Physhical Activity, Sleep Duration, Breakfast and Fast Food Consumption Habits with The Prevalence of Overweight Among Elementary School Children', Nutri-Sains: Jurnal Giz̨i, Pangan dan Aplikasinya. doi: 10.21580/ns.2018.2.2.2588.

PERGIZI PANGAN Indonesia (2013) 'Deklarasi Pekan Sarapan Nasional (Pesan)', Pusat Penganekaragaman Konsumsi dan Keamanan Pangan Badan Ketahanan Pangan, January, pp. 0-37.

Phillips, G. (2005) 'Does Eating Breakfast Affect the Performance of College Students on Biology Exams?.', Bioscene: Journal of College Biology Teaching, 30(4), pp. 15-19.

Stefani, Megah; Kustiyah, L. (2019) 'Relationship between breakfast habits and sleep duration and academic achievement of elementary school children', Poster of 13th Asian Congress of Nutrition, pp. 1-4. 